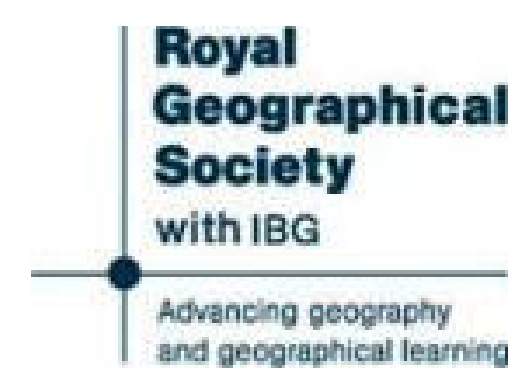

Western Uganda: Discussion

Author(s): J. F. Cunningham, Canon Smith and C. Rodney Mundy

Source: The Geographical Journal, Vol. 24, No. 3 (Sep., 1904), pp. 263-267

Published by: The Royal Geographical Society (with the Institute of British Geographers)

Stable URL: http://www.jstor.org/stable/1776580

Accessed: 01/02/2015 05:09

Your use of the JSTOR archive indicates your acceptance of the Terms \& Conditions of Use, available at

http://www.jstor.org/page/info/about/policies/terms.jsp

JSTOR is a not-for-profit service that helps scholars, researchers, and students discover, use, and build upon a wide range of content in a trusted digital archive. We use information technology and tools to increase productivity and facilitate new forms of scholarship. For more information about JSTOR, please contact support@jstor.org. 
Protectorate, are willing to direct our interests in not only this western province, but Uganda as a whole.

The Uganda railway has cost the British Government $£ 7,000,000$ to construct. What return have we got to justify this great outlay? We have, in the words of Lord Rosebery, "pegged out a claim for futurity." We are effectually able to contrul the headwaters of the Nile, which is the life of Egypt. The slave trade has received its death-blow, and the warships which looked after the slavers on the East Coast can now be used elsewhere. The cruelties of human porterage have disappeared, and inter-tribal wars have ceased. The missionaries have been able to carry on their good work in peace; thousands of the natives have become Christians, and under the present enlightened policy of our able and kindly High Commissioner, Colonel Hayes Sadler, c.в., education is encouraged and industries fostered. In short, the Uganda Protectorate is like a spring day, everything bursting into life.

The implicit trust and confidence which the inhabitants have in Colonel Hayes Sadler and his able Deputy-Commissioner, Mr. George Wilson, c.B., have increased their loyalty to our nation, and have inclined them to settle down to the development of their country, so that we may look, in the near future, for a very large increase in the export of coffee and cotton from the Protectorate.

The Uganda Protectorate is, in my opinion, the greatest asset of our nation in all East Africa. The inhabitants are to a great extent Christian, exceedingly intelligent, progressive, and most loyal-facts which will always secure the peace, not only of the Protectorate, but also of the surrounding territory.

Before the reading of the paper, the President said: I hare pleasure in introducing to the meeting one of those pioneer missionaries, Mr. Fisher, who for the last fifty years have done so much for the exploration of Africa. He will give you an account of his experience in Western Uganda, which I feel quite sure will be extremely interesting and valuable. I now call upon Mr. Fisher to address you.

After the reading of the paper-

Mr. J. F. Cunningham: I fear I have very little to say, except to give expression to what all of us feel-our gratification at the interesting address that we have heard. Most of you, perhaps, think that it is quite easy to write original matter regarding Uganda and the territories adjoining. But $I$ think you would alter that opinion if you tried it. No Society knows better than you how many able men have visited that district, and how thoroughly they have described it. I might mention General Lugard, Sir Harry Johnston, Mr. Moore, Major Powell-Cotton, and Mr. Grogan-all of them very careful observers and admirable descriptive writers. Where these men have travelled and described, it is not an easy matter to pick up new information, and yet Mr. Fisher has managed to get a great amount of original information together. I think I know why. Mr. Fisher is known locally as a very expert linguist; he knows several native 
languages, and he has lived in close personal relations with the tribes he has described. It is to that, I think, we owe the essence of the interesting discourse to which we have listened. There are certain subjects-botany, for instance-that the ordinary traveller may describe. Botany has no secrets; its history is written on the leaves and stems of every plant. The same may be said of geology to a certain extent, because geology has an outcrop to guide the observer and the traveller; but to describe the intimate personal habits of these tribes cannot be done without an intimate knowledge of the language of these people. That Mr. Fisher has. What strikes me as most remarkable is that he should have described all these people without a trace of exaggeration in any one particular that I can allude to. I have collected some information myself regarding these people, and may at once say that I owe it, not to myself personally, but to the information I have been able to glean from the missionaries. When a missionary settles down in any one particular district, his first aim and object is to master the language of that district. Having mastered it, his station becomes a centre of religious instruction; not only that, but it becomes a centre of secular instruction also, and, as you have seen from the photographs shown on the screen, not only are these mission stations centres of secular and religious instruction, but a considerable amount of work is done in the matter of handicraft. You have seen how the natives have been taught to make bricks, and how they bave been taught to build bouses of a serviceable kind. All that is the work of the missionaries. Now, Mr. Fisher bas covered almost the whole of this map that $I$ have in my hand, and I am afraid of keeping you too long, but in regard to the Bahima peopleand just to start a discussion for any one who wishes to follow-in regard to the origin of these tribes and the other tribes along there in Ankole and Toro, I might mention that $I$ have found an additional matter on which to base, in a slight way, a kelief in the fact that these people are of a northern origin. $\mathrm{Mr}$. Fisher has alluded to a certain method of hairdressing amongst the Bankole, and other matters. Now, in addition to that, the women of Ankole are a very closely veiled people; they never expose their features, and they are always confined to their private apartments. As you know, that is not a Central African custom; it has a tendency to lead one to Egypt to account for that, and I believe the white man-the Kintu that Mr. Fisher referred to-would be considered white if he were an Egyptian coming amongst these people, who are perfectly black. On the other hand, I have made a great many measurements of the heads of the Ankole people, and I find that they are dolichocepbalic, and this leads one to the conclusion that in that one respect they resemble the Somalis and the Egyptians. Now, the Ankole people have a religious belief in a future state. Mr. Fisher has not touched on that; but the King of Ankole himself and his ministers told me that the future state for the elect is called Mitoma. It is not placed in Ankole, but it is far away beyond German territory, and the entrance to that place is a sort of mystic tunnel in the Ankole forest. The king himself gave me an imitation of the noises made by the spirits in passing into that tunnel. I am sorry I cannot attempt an imitation. Well, this state is a state of perfect rest-there are no clothes required there; there is no herding of cattle, no work, no cultivation of bananas, no food required, no drink, and, mind you, it is not intended for the righteous alone. The wicked go there as well as the good. Every one is admitted there except the peasantry. The Bairu, or working class, are not admitted to the Mitoma of the Ankole people. Not only are the Ankole people interesting in this way, but they have given to the Bakonjo people a god. This god, I found out from the people themselves, was originally an Ankole man. He was driven out of Ankole, and he was accepted by the Bakonjo. A 
man, you know, is never a prophet in his own country. His great qualification for being a deity was not a small one in this twentieth century - he was bullet-proof; he was also spear-proof, and these two qualifications alone were quite sufficient to recommend him to a naked people who were not bullet-proof. I have asked one of the officials of the Geographical Society to prepare a lantern slide showing three of these people worshipping at what they call the temple of their ancestors.

Now look at this picture of the hukiko sitting in session. That is the Uganda parliament. You see, as in your parliament, they are ranged in two columns, but they are not in opposition. 'That is the king in the chair, in the dark over there, and these are the leading chiefs. If it would not be too wearisome, I will tell you how the house is composed. There are eighty-nine members. I was almost tempted to call it the mother of parliamente, because, I believe, it was in existence before our own, but its present constitution was given to it by Sir Harry Johnston. Uganda is divided into twenty provinces; each province has a separate member who draws $\$ 200$ a year. There are thrce Regents and twenty county members. Each county also selects three of its notables. We have not got to any ballot-box election at the present time, but public opinion points out who are the distinguished men of the county, and these people take their seats in this parliament. In addition to them, there are important persons who may be connected with the royal house of Uganda, or who have distinguished themselves either in the past or in fighting for or against the mutineers, or in some other way, and these are entitled to a seat in this House-making eighty-nine members. Now, there is no dissolution in this house, because, I suppose, there are no parties. Probably that will come later on. But, at all events, a member of this house, if he becomes obnoxious to the king, cannot be removed on account of expressing his opinions freely. The Commissioner on behalf of the Government has a veto in removing any man, so that prevents any unjust treatment so far as a free expression of opinion is concerned.

Rev. Canon SMith : I will only speak just a few moments, and the interest of what I have to say lies in the direction of pointing out what extraordinary progress has been made during the last fourteen years. Fourteen years ago I was journeying to Uganda through German territory, and at that time the country scarcely belonged to us at all. It is since those days that we have acquired, without dispute, the territory of Uganda, and I can recollect the time when General Macdonald came into Uganda for the purpose of surveying for the railway. I can also remember when there was only one church in the whole of the Uganda Protectorate. I can also remember when the first octagonal house was being built, and at that time it was necessary to hold sticks and threats over those who carried on the work. When I mention this, you will understand what extraordinary progress has been made during the last fourtcen years. Some intensely interesting questions have been raised by the remarks of Mr. Fisher to-night, and I had hoped there might have been time to speak abuut them. I will only refer to one of these questions to which I allude, namely, the distribution of the black man over the whole of Africa. From which point did that distribution commence? is a question suggested to my mind to-night. My own belief is that it began from the northeastern part of Atrica, and the black people have been gradually driven across to the West Coast. I make this remark partly because it is my duty now to work on the West Coast, and it is only a week since I landed from Sierra Leone, and during my work there I have been intensely interested in noticing questions and subjects of similarity and dissimilarity from those things I observed on the East Coast. And just speaking for a moment, I would suggest one or two special subjects which this Society through its members might make a study of. I believe

No. III.-SEPTEMBER, 1904.] 
we have paid far too little attention to the mourning and burial customs of these people. Then, again, I think we have shown far too little notice to the signs of primitive art which may be discovered throughout the whole of Africa. Some are extremely primitive, but they are all suggestive; and I think if we pursue the question, we shall yet learn a great deal about the past history of these people. I would only say one more thing, and that is, there was a photograph shown which referred to the extraordinary character of the waves on Victoria Nyanza. Twice I have crossed the lake, and, curiously enough, I was one of those who cccupied a boat during that particular storm the picture of which was shown to you to-night. That picture was taken by Bishop Tucker, and I was with him when it was taken. Now, I have travelled over the ocean both on the east and west coasts of Africa, and I can assure you I have never seen any condition of the ocean waves which seemed to correspond in magnitude with the waves on the Victoria Nyanza. I think that is a subject of interest, and it leads us to inquire how these gigantic forces are brought into existence, and what they all mean, in the course of our future studies.

The President: I think we must now thank Mr. Fisher for his most interesting paper. The pioneer missionaries of Africa, from the days of my old friend Dr. Livingstone until now, have done a very large share-more, I think, than their proper share-a very large share indeed of the exploration of this great continent. We have recognized their work on more than one occasion by giving our Gold Medals to pioneer missionaries and our other Awards, but I do not think any of those missionaries have excelled Mr. Fisher in the careful studies he has made of the tribes with which he has come in contact. I am sure none have given us a more interesting evening. I propose, therefore, to you that you should pass a very cordial vote of thanks to Mr. Fisher for his paper, and also, as Mr. Cunningham has suggested to us, that we should combine with that vote the name of Mrs. Fisher. I think we are also bound to thank Mr. Cunningham and Canon Smith for their most interesting addresses.

Had time permitted, Captain C. Rodney Mundy would have made the following remarks: There are one or two points in the interesting lesture we have heard tonight to which I should like to briefly refer. In the first place, with regard to the origin of the Ba-Hima, many things seem to point to their having come from the north-east, and of a Semitic rather than a Hamitic stozk; and I think there can be very little doubt that they were originally a light-skinned race, although there are now plenty of dark Ba-Hima to be found-this, I think, being due to a mixture of negro blood. They are, of course, a purely pastoral race of cattle-breeders, and the true Mhima will not touch anything bat beef, milk, cold water, thoroughly despising the banana and all its products. Neither will he touch mutton, even when almost starving, nor grain. Now, it is an interesting fact that there is in Central Africa another race of originally light-skinned, thin-lipped, Semitic people, who are in their original state pure cattle-breeders, and are nomadic equally with the Ba-Hima. I refer to the Fulani or Fulbe, who, although they are now the ruling race in a large part of the hinterland of West Africa, were originally merely nomadic herdsmen. When I was in Northern Nigeria, and conducting a few inquiries into the habits, etc., of the still nomad portion of the Fulani, I was very much interested to discover several words and expressions, especially connected with their cattle, which are identically the same in Fulani and Lu-Hima. The origin of the Fulani is also lost in obscurity. Is it not possible that both these races are descended from some common stock, and have migrated in divergent directions from somewhere to the north or north-west of Darfur? Secondly, with regard to what Mr. Fisher has told us with regard to lakes 
Albert Edward and Edward having formerly been much nearer together than at present-there is plenty of evidence to show that Lake Albert Edward was once much larger than it is at present. I was particularly struck with the unmistakable proofs I found that the southern shore has long been receding northward, and is still doing so at the present day, at a fairly rapid rate. On the other hand, there is some reason for thinking that before the Mfumbiro chain of volcanoes was thrown up the drainage of Lake Albert Edward was south to Lake Tanganyika, and not north to Lake Albert; and these volcanoes cannot be of very ancient date.

\title{
GEOGRAPHICAL DISTRIBUTION OF VEGETATION OF THE BASINS OF THE RIVERS EDEN, TEES, WEAR, AND TYNE.*
}

\author{
By FRANCIS J. LEWIS, F.L.S., Assistant Lecturer in Botany, \\ University of Liverpool.
}

\section{PART II.}

ThE area now under consideration lies immediately to the north of Part I., the eastern and western boundaries of the two maps being continuous. The field work for this paper was begun at the same time as Part I., and was finished last autumn. The boundaries of the various plant associations have been laid down upon the 6-inch Ordnance maps in the field, and subsequently reduced on to the 1-inch maps for publication. The maps now published are contoured every 100 feet up to 1000 feet, then every 250 feet up to 2000 feet, and above this height the contours are given every 500 feet. The lower limit of the Alpine moorland follows the 2000-feet contour-line very closely, but elsewhere the plant boundaries have no direct connection with the contour-lines, frequently running at right angles to them. The boundaries have been fixed by the landmarks shown upon the large-scale maps, such as piles of stones, sheepfolds, scars, and streams] The height of most of these landmarks are given on the 6-inch maps, and can easily be identified with the aid of a good aneroid registering to 50 feet, the aneroid being frequently checked during the day by means of the summits.

\section{TOPOGRAPHY.}

The area now under consideration covers the rising ground of the Tees, South Tyne, and Wear, and includes Sheet 25 and part of Sheet 24 of the 1-inch Geological Survey. The water-partings consist of two main ridges, the Cross Fell chain on the west forming the waterparting of the Tees and Tyne and part of the drainage system of the Eden, and the Weardale Fells on the east. The former ridge trends north-west and south-east, and rises abruptly from the Eden valley to a height of 2930 feet on Cross Fell, and does not fall below 2500 feet

* Continued from vol. xxiii. p. 331. Map, p. 376 . 